\title{
Impacts of alien invasive plants on soil nutrients are correlated with initial site conditions in NW Europe
}

\author{
Nicolas Dassonville ${ }^{1}$, Sonia Vanderhoeven ${ }^{2}$, Valérie Vanparys ${ }^{3}$, Mathieu Hayez ${ }^{1}$, Wolf Gruber ${ }^{1}$, Pierre Meerts ${ }^{1}$ \\ 1 Laboratoire de Génétique et Ecologie Végétales, Université Libre de Bruxelles (ULB), 1850, chausée de Wavre, 1160 Bruxelles, Belgium. \\ 2 Laboratoire d'Ecologie, Faculté Universitaire des Sciences Agronomiques de Gembloux (FUSAGx), Gembloux, Belgium. \\ ${ }^{3}$ Unité de Génétique, Université Catholique de Louvain-la-Neuve (UCL), Louvain-la-Neuve, Belgium.
}

\begin{abstract}
Alien invasive plants are capable of modifying ecosystem function. However, it is difficult to make generalisations because impacts often appear to be species- and site-specific. In this study, we examined the impacts of seven highly invasive plant species in NW Europe (Fallopia japonica, Heracleum mantegazzianum, Impatiens glandulifera, Prunus serotina, Rosa rugosa, Senecio inaequidens, Solidago gigantea) on nutrient pools in the topsoil and the standing biomass. We tested if the impacts follow predictable patterns, across species and sites or, alternatively, if they are entirely idiosyncratic. To that end, we compared invaded and adjacent uninvaded plots in a total of 36 sites with widely divergent soil chemistry and vegetation composition. For all species, invaded plots had increased aboveground biomass and nutrient stocks in standing biomass compared to uninvaded vegetation. This suggests that enhanced nutrient uptake may be a key trait of highly invasive plant species. The magnitude and direction of the impact on topsoil chemical properties were strongly site-specific. A striking inding is that the direction of change in soil properties followed a predictable pattern. Thus, strong positive impacts (higher topsoil nutrient concentrations in invaded plots compared to uninvaded ones) were most often found in sites with initially low nutrient concentrations in the topsoil, while negative impacts were generally found under the opposite conditions. This pattern was significant for potassium, magnesium, phosphorus, manganese and nitrogen. The particular site-specific pattern in the impacts that we observed provides the first evidence that alien invasive species may contribute to a homogenisation of soil conditions in invaded landscapes.
\end{abstract}

Keywords : Biological invasions ; homogenisation ; nutrient cycling ; species effects ; topsoil mineral nutrients.

\section{INTRODUCTION}

During the last decade, the impacts of alien invasive plants on ecosystems have received growing attention. These species alter ecosystems because they difer from natives in ecophysiological traits, such as growth and allocation patterns (Wilsey and Polley 2006; Liao et al. 2008). Many alien invasive species have been shown to afect plant and animal communities (Braithwaite et al. 1989; Alvarez and Cushman 2002), ecosystem functioning (D'Antonio 1992; Belnap and Philips 2001), soil properties and nutrient fluxes (Asner and Beatty 1996; Blank and Young 2002) in the sites they invade. Not surprisingly, the documented impacts on soil properties are diverse. While most published studies report increased soil nutrient stock and/or availability under invasive plant species compared to uninvaded ecosystems (Musil 1993; Scott et al. 2001; Duda et al. 2003; Vanderhoeven et al. 2005; Chapuis-Lardy et al. 2006; Liao et al. 2008), other studies show the opposite pattern (Christian and Wilson 1999; Leary et al. 2006). In addition, the same species may have different impacts, depending on local conditions (Stock et al. 1995; Meyerson et al. 2000; Belnap and Philips 2001; Scott et al. 2001). The general approach of most previous studies investigating the impacts of alien invasive plants was to consider only a single species in one or very few sites. A large number of different methods were also used. Consequently, generalisation on the ecological impacts of invasive plant species is difficult. Based on a literature review, Ehrenfeld (2003) stated that soil carbon (C) and nutrients pools were often modified by invasions and that the direction and magnitude of the impacts were probably determined by the composition of the invaded community and soil properties. One of the aims of our study was to examine the relationship, if any, between initial soil conditions and the direction and magnitude of impacts, based on a large sample of species and sites and with a common methodology.

In Europe, many alien invasive plant species have dramatically increased their range during the last decades (Pysek 1991; Pysek and Prach 1995; Muller 2004; Williamson et al. 2005). It is important to test if invaded ecosystems are 
modified in a systematic and predictable way. This may well be the case because invasive species often share common functional traits which promote invasiveness (Grotkopp et al. 2002). Invaded ecosystems also share common attributes making them susceptible to invasion (Alpert et al. 2000; Davis et al. 2000) and which may result in similar impacts.

In this study, we examined the impacts of seven highly invasive plant species on soil nutrients at 36 sites in Belgium. We also examined nutrient pools in aboveground biomass.

The specific questions addressed are:

- Are there general patterns in the impacts of these highly successful invasive species on soil nutrients?

- Alternatively, do impacts vary depending on initial soil chemical properties prior to invasion (site effect)? If so, do impacts follow some predictable pattern or are they completely idiosyncratic?

- Are impacts on soil nutrients explained by differences in nutrient use between native and alien species?

\section{MATERIALS AND METHODS}

\section{Species selection}

Seven species were selected for study: Impatiens glandulifera (annual), Heracleum mantegazzianum (hemicryptophyte), Senecio inaequidens (chamaephyte), Solidago gigantea, Fallopia japonica (perennial rhizomatous geophytes), Rosa rugosa (woody shrub) and Prunus serotina (tree). All of these species can form monospecific stands in invaded communities and are recognised as being among the most highly invasive plant species in Belgium and elsewhere in Europe (Pysek 1991; Pysek and Prach 1995; Verloove 2002; Muller 2004; Verloove 2006).

\section{Site selection}

For each species, five or six sites were selected in ecosystems with contrasting resident vegetation structure and composition, in an attempt to sample the range of habitats colonised by the study species in Belgium. In all selected sites, vegetation structure is profoundly afected by invasion, with alien species generally forming pure stands. The sites fulfilled the following conditions: (1) having well-established and still expanding populations of the target species surrounded by native uninvaded vegetation; (2) having suiciently homogeneous soil. Site selection aimed at minimising the probability of diferences existing prior to the invasion event. To that end, invaded and control uninvaded plots within a site were in the same topographic situation and had the same soil texture (see Vanderhoeven et al. 2005 for methods). Moreover, the uninvaded control plots were located as close as possible to the front of expansion of the invader. Therefore, systematic differences between invaded and uninvaded soils, if any, can reasonably be ascribed to the contrasted plant cover. The sample comprises sites with widely divergent plant cover (from open grassland in sand dunes to alluvial eutrophic forest), in line with the contrasted ecological niches of the seven alien invasive species. In most sites, invasion typically dates back to two or three decades.

\section{Soil sampling}

At each site, six $1-\mathrm{m}^{2}$ plots were located in invaded patches and six $1-\mathrm{m}^{2}$ plots were located in adjacent, uninvaded vegetation. Soil was sampled from February to April 2004. In each plot, five soil cores $(0-10 \mathrm{~cm}$, litter discarded $)$ were collected with a soil borer $(4 \mathrm{~cm}$ in diameter, one core at each corner of the square and one core at the centre of the square). These five cores were mixed up into a single bulk sample for each plot. Soil samples were air-dried and sieved $(<2 \mathrm{~mm})$.

\section{Soil analysis}

The following parameters were assessed on each sample: soil $\mathrm{pH}$, exchangeable magnesium $(\mathrm{Mg})$, potassium $(\mathrm{K})$, zinc $(\mathrm{Zn})$, manganese $(\mathrm{Mn})$ and phosphorus $(\mathrm{P})\left[1 \mathrm{M} \mathrm{CH}_{3} \mathrm{COONH}_{4} \mathrm{pH} 4.65\right.$ extraction and inductively coupled plasmaoptical emission spectroscopy (ICP-OES) determination]. Exchangeable calcium (Ca) was not determined because a substantial proportion of soil samples contained free $\mathrm{CaCO}$. Organic $\mathrm{C}$ and nitrogen $(\mathrm{N})$ content were also assessed with a dry combustion C-N analyser (NC-2100; Carlo Erba Instruments, Milan, Italy) and the C:N ratio was then computed. For further methodological details, see Vanderhoeven et al. (2005).

\section{Nutrients in standing biomass}

Aboveground biomass was harvested in invaded and control plots at the peak of biomass (between June and August) for four of the seven species (H. mantegazzianum, P. serotina and R. rugosa were not sampled for practical reasons) on the 
same plots as for soil sampling. Standing dead stems were discarded and, therefore, the harvested biomass can be used as a proxy for the annual production. Species were not sorted before weighing. However, in the invaded plots, the contribution of native species was always negligible. The plant samples were dried at $70^{\circ} \mathrm{C}$ to constant weight. A representative subsample was finely ground $(0.12 \mathrm{~mm})$ and analysed for $\mathrm{Mg}, \mathrm{K}, \mathrm{P}, \mathrm{Mn}$ and $\mathrm{Zn}$ concentration $\left(550^{\circ} \mathrm{C}\right.$ calcination, $\mathrm{HCl}$ dissolution of the ashes and ICP-OES determination). Carbon and $\mathrm{N}$ contents were assessed using a dry combustion C-N elemental analyser (model NC-2100; Carlo Erba Instruments). The aboveground nutrient stock $\left(\mathrm{mg} \mathrm{m}^{-2}\right)$ was then calculated as the product of mineral nutrient concentration and biomass. For further technical details, see Vanderhoeven et al. (2005).

\section{Statistical analyses}

For soil and plant parameters, a three-way nested ANOVA was applied on all sites and the species pooled, with species (fixed factor), site (random factor, nested in species) and invasion (fixed factor) as the main efects. In this analysis, significant species $\times$ invasion and site (species) $\times$ invasion interactions will point to diferences in the impacts of invasion among species and sites, respectively.

Log transformation was applied as necessary to meet the assumptions of ANOVA. Relationships between the magnitude of impacts on soil chemical properties and initial site conditions were examined using two approaches. First, the impact magnitude, expressed as the diference between values of each parameter in invaded stands $(I)$ and uninvaded stands $(U)$, was plotted against values in uninvaded stands $(U)$. The correlation between the impact magnitude and values in uninvaded stands was calculated. When necessary, the correlation was computed on log-transformed data $(\mathrm{Mg}, \mathrm{P}, \mathrm{Mn}$, $\mathrm{Zn}$ ), and the magnitude of impact was calculated as the difference between log (invaded value) and log (uninvaded value). Secondly, a regression analysis was conducted. To avoid autocorrelation, impacts $(I-U)$ were not regressed directly against values in uninvaded stands $(U)$. Instead, values in invaded stands $(I)$ were regressed on values in uninvaded stands $(U)$. Under the null hypothesis of no impact, all data points align on the line $I=U$. Deviation from this line, in the form of $I=b+a U$, indicates departure from the null hypothesis. Intercept $(b)$ values $>0$ and $<0$ indicate positive and negative impacts, respectively. Slope $(a)$ values $>1$ and $<1$ indicate that impacts increase and decrease with initial conditions, respectively. Conformity tests of intercept and slope were performed. Regression analyses were performed on log-transformed values as necessary to meet normality assumptions. Analyses were performed using Statistica ver.7.1 software (StatSoft Inc. 2005).

\section{RESULTS}

The seven species considered in our study strongly modified the plant community structure with the formation of (quasi) monospecific stands. Sampled sites spanned a very broad range of vegetation and soil types (Table 1).

\section{Soil}

The 36 sites spanned a very broad range of soil conditions (Fig. 1) (45-fold variation for K, 40-fold for P, 248-fold for $\mathrm{Zn}$, 64-fold for organic C, 44-fold for $\mathrm{Mn}$, 35-fold for $\mathrm{Mg}$, 32-fold for $\mathrm{N}$ ). The results of the three-way ANOVA on topsoil chemical properties are shown in Table 2.

\section{Species effects}

The species factor was significant for all elements except $\mathrm{P}$ and $\mathrm{Zn}$ (Table 2), which indicates that all of the species studied do not share a common soil niche. For $\mathrm{pH}, \mathrm{C}$ and N, the species effect can be accounted for by two species. Thus, sites with $P$. serotina and $R$. rugosa occupied the lowest and the highest end of the $\mathrm{pH}$ range, respectively (Fig. 1). Rosa rugosa was restricted to sites with the lowermost concentrations of organic $\mathrm{C}$ and $\mathrm{N}$ in our sample (maritime sand dunes).

\section{Site effect}

The site (within-species) effect was also highly significant for all parameters (Table 2), indicating that, despite different ecological optimum between species, many species in our sample tend to occupy a relatively broad soil niche. A tenfold variation in nutrient concentrations across sites within species was not rare; for example, there was a 51-fold variation observed for $\mathrm{K}$ in sites invaded by $P$. serotina, a 40-fold variation observed for $\mathrm{P}$ in sites invaded by $S$. gigantea and a 19-fold variation observed for $\mathrm{Mg}$ in sites invaded by I. glandulifera. 
Table 1. Sites localisation and characterisation: vegetation and soil type (FAO, ISRIC, IUSS, 1998).

\begin{tabular}{|c|c|c|c|}
\hline Species & Localisation & Invaded vegetation & Soil type \\
\hline \multirow{5}{*}{$\begin{array}{l}\text { Heracleum } \\
\text { mantegazzianum }\end{array}$} & Crombach & Wet grassland with Phalaris arundinacea & Fluvisol \\
\hline & Ganshoren & Wet wasteland with Urtica dioica and Petasites hybridus & Gleysol \\
\hline & Koersel & Dry grassland with Festuca ovina & Arenosol \\
\hline & Boitsfort & Willow scrub & Gleysol \\
\hline & Boitsfort & Willow scrub & Gleysol \\
\hline \multirow[t]{6}{*}{ Fallopia japonica } & Boitsfort & $\begin{array}{l}\text { Forest pond bank with Petasites hybridus and Chrysosplenium } \\
\text { oppositifolium }\end{array}$ & Gleysol \\
\hline & Gembloux & Cultivated ield margin with Urtica dioica and Rubus sp. & Anthrosol \\
\hline & Haren & $\begin{array}{l}\text { Oldield with Dactylis glomerata, Urtica dioica and Cirsium } \\
\text { arvense }\end{array}$ & Anthrosol \\
\hline & Boitsfort & Beech forest & Luvisol \\
\hline & Saint-Ghislain & $\begin{array}{l}\text { Mesic rough grassland with Calamagrostis epigejos, Eupatorium } \\
\text { cannabinum, Achillea millefolium... }\end{array}$ & Luvisol \\
\hline & Boitsfort & Wasteland with Urtica dioica & Anthrosol \\
\hline \multirow[t]{5}{*}{ Solidago gigantea } & Saint-Ghislain & $\begin{array}{l}\text { Mesic rough grassland with Calamagrostis epigejos, } \\
\text { Arrhenatherum elatius... }\end{array}$ & Luvisol \\
\hline & Boitsfort & Wasteland with Urtica dioica & Anthrosol \\
\hline & Kraainem & $\begin{array}{l}\text { Rough grassland with Agrostis sp., Holcus lanatus, } \\
\text { Leucanthemum vulgare, Senecio jacobaea... }\end{array}$ & Gleysol \\
\hline & Woluwe & $\begin{array}{l}\text { Rough grassland with Dactylis glomerata and Arrhenatherum } \\
\text { elatius }\end{array}$ & Luvisol \\
\hline & Marche-les-Dames & Wasteland with Tanacetum vulgare, Rubus sp., Origanum vulgare & Luvisol \\
\hline \multirow{5}{*}{$\begin{array}{l}\text { Senecio } \\
\text { inaequidens }\end{array}$} & Koersel & Dry grassland with Festuca ovina & Arenosol \\
\hline & Harchies & $\begin{array}{l}\text { Open dry vegetation with Hypericum perforatum and Fragaria } \\
\text { vesca }\end{array}$ & Arenosol \\
\hline & Antwerpen & Wasteland with Senecio jacobaea and Melilotus albus & Cambisol \\
\hline & De Panne & Coastal sand dune with Ammophila arenaria & Arenosol \\
\hline & Antwerpen & Open dry vegetation with Sedum acre & Arenosol \\
\hline \multirow{5}{*}{$\begin{array}{l}\text { Impatiens } \\
\text { glandulifera }\end{array}$} & Uccle & Small valley in a beech forest & Gleysol \\
\hline & Temse & Phragmites australis & Gleysol \\
\hline & Kessel & Riverbank with Phalaris arundinacea and Urtica dioica & Gleysol \\
\hline & Muizen & Riverbank with Phalaris arundinacea and Urtica dioica & Gleysol \\
\hline & Ways & $\begin{array}{l}\text { Poplar plantation clearcut with Galeopsis tetrahit and Urtica } \\
\text { dioica }\end{array}$ & Luvisol \\
\hline \multirow[t]{5}{*}{ Prunus serotina } & Uccle & $\begin{array}{l}\text { Rough grassland with Dactylis glomerata and Arrhenatherum } \\
\text { elatius }\end{array}$ & Luvisol \\
\hline & La Hulpe & Young forest with Betula pendula and Sorbus aucuparia & Podzol \\
\hline & Louvain-La-Neuve & Beech forest & Luvisol \\
\hline & Kessel & $\begin{array}{l}\text { Mixed forest with Quercus robur, Acer pseudoplatanus, Betula } \\
\text { pendula... }\end{array}$ & Luvisol \\
\hline & Westerlo & Pine plantation with Betula pendula and Sorbus aucuparia & Podzol \\
\hline \multirow[t]{3}{*}{ Rosa rugosa } & Oostduinkerke & $\begin{array}{l}\text { Coastal sand dune with Hippophae rhamnoides and Ammophila } \\
\text { arenaria }\end{array}$ & Arenosol \\
\hline & Nieuwpoort & $\begin{array}{l}\text { Coastal sand dune with Hippophae rhamnoides and Ammophila } \\
\text { arenaria }\end{array}$ & Arenosol \\
\hline & Bredene & $\begin{array}{l}\text { Coastal sand dune with Hippophae rhamnoides and Ammophila } \\
\text { arenaria }\end{array}$ & Arenosol \\
\hline
\end{tabular}


Wenduine

Zeebrugge
Coastal sand dune with Hippophae rhamnoides and Ammophila Arenosol arenaria

Wet depression in a coastal sand dune with Phragmites australis Arenosol and Arrhenatherum elatius

Fig. 1. Impact of invasive species on soil chemical properties ( $p H$, exchangeable cations and $P$ concentrations and organic $C$ and $N$ concentrations) as a function of soil chemical properties in uninvaded plots (U). Impact is calculated as the diference between the value of the parameter in invaded plots (I) minus the value of the parameter in uninvaded plots $(U)$. A positive value of $I-U$ indicates an increased concentration of that element in the invaded soil. Pearson correlation coeicient $(r)$ between $U$ and I - U. Significance levels $\left({ }^{*} p<0.05,{ }^{* *} p<0.01,{ }^{* * *} p<0.001\right) . \log$ transformed data for Mg,, , Mn, Zn. Filled diamond Solidago gigantea, filled square Fallopia japonica, filled triangle Heracleum mantegazzianum, open triangle Impatiens glandulifera, open circle Rosa rugosa, open diamond Senecio inaequidens, open square Prunus serotina.
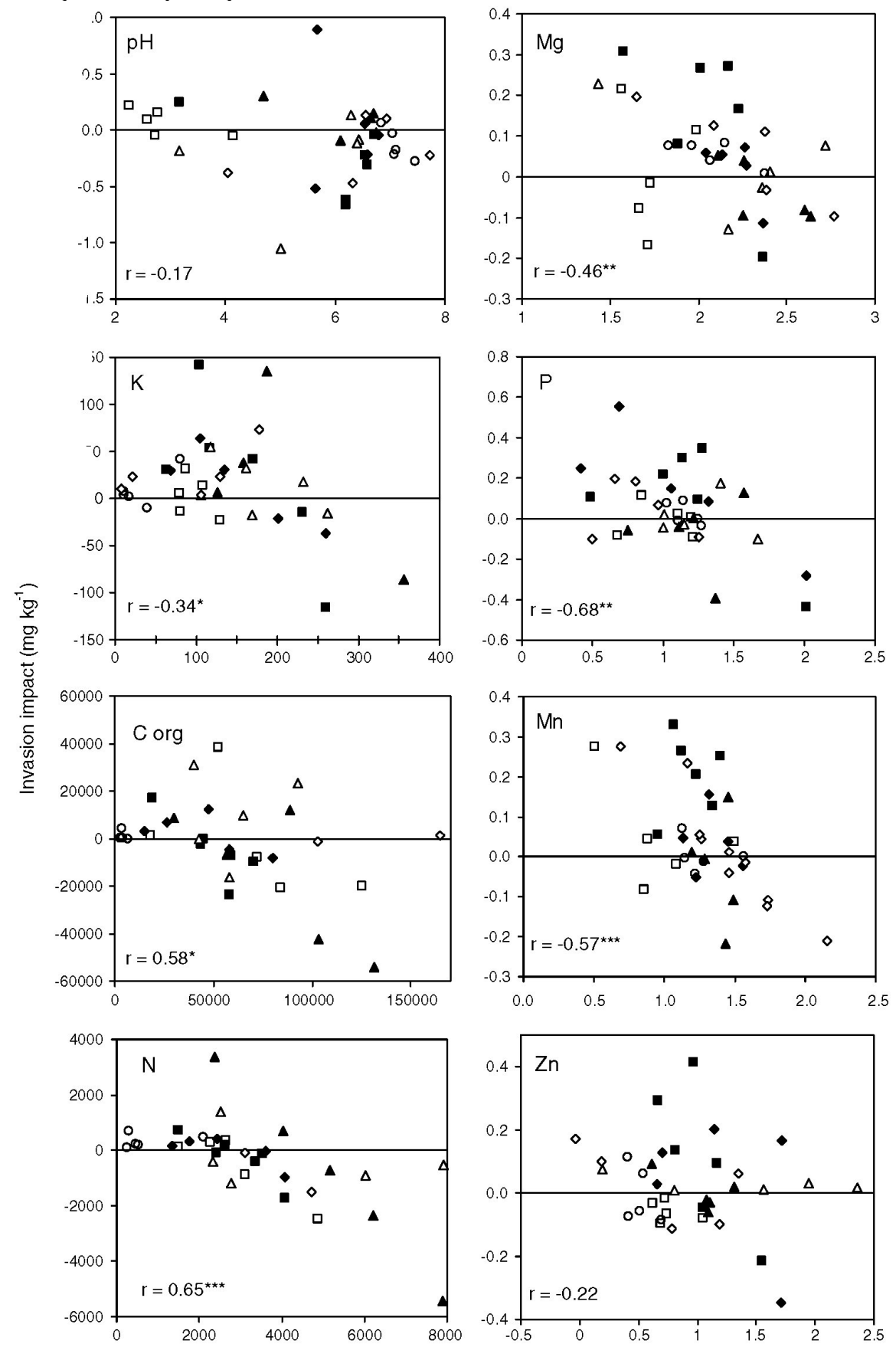

$\mathrm{pH}$ and soil element concentrations $\left(\mathrm{mg} \mathrm{kg}^{-1}\right)$ in uninvaded plots 
Table 2. Three-way ANOVA for topsoil chemical properties ( $p H$, concentrations of cations and $P$ extracted with $\mathrm{CH}_{3} \mathrm{COONH}_{4} \mathrm{pH} 4.65$, and concentrations of organic $\mathrm{C}$ and $\mathrm{N}$ in the 0-to 10-cm topsoil horizon).

\begin{tabular}{|c|c|c|c|c|c|c|c|c|c|c|}
\hline & $d f$ & pH & $\mathbf{K}$ & Mg & $\mathbf{P}$ & Mn & Zn & C organic & $\mathbf{N}$ & $\mathrm{C}: \mathrm{N}$ \\
\hline Species & 6 & & $6.2 * * *$ & $2.9 * * *$ & 0.9 & $3.1^{*}$ & 2.2 & $3.6 * *$ & $3.3^{*}$ & $3.7 * *$ \\
\hline Site (species) & 29 & $38.3 * * *$ & $13.0 * * *$ & $17.8 * * *$ & $11.6^{* * *}$ & $12.1 * * *$ & $80.8 * * *$ & $17.0 * * *$ & $30.6 * * *$ & $19.3 * * *$ \\
\hline Invasion & 1 & 2.6 & $10.5^{* *}$ & $4.7^{*}$ & 1.5 & 3.4 & 0.3 & 0.4 & 0.5 & 1.3 \\
\hline Species $\times$ invasion & 6 & 1.1 & 0.7 & 1.2 & 0.7 & 1.8 & 0.2 & 1.1 & 1.9 & 1.1 \\
\hline Site $(\mathrm{sp}) \times$ invasion & 29 & $2.9 * * *$ & $4.6 * * *$ & $4.8 * * *$ & $5.7 * * *$ & $2.8 * * *$ & $2.9 * * *$ & $2.4 * * *$ & $3.3 * * *$ & $3.9 * * *$ \\
\hline
\end{tabular}

Species and invasion are ixed factors and site within species is a random factor.

\section{Invasion and species $\times$ invasion effect}

The invasion effect and the interaction invasion $\mathrm{x}$ species efect were mostly not significant (Table 2), indicating that the magnitude and direction of the invasion impact were not systematically the same between cases and that these did not strongly depend on species identity. The failure to detect an overall impact of invasion and differences in impact among species (species $\times$ invasion interaction) is due to the pervasive site $\times$ invasion interactions. Potassium stands out as an exception, with a significant invasion effect. In 26 of the 36 sites, the soil showed increased K availability under invasive plants compared to uninvaded plots (Fig. 1).

\section{Site $\times$ invasion interaction}

The site $\times$ invasion interaction was highly significant for all soil parameters $(\mathrm{pH}$, exchangeable cations and $\mathrm{P}$ concentrations and organic $\mathrm{C}$ and $\mathrm{N}$ concentrations) (Table 2), indicating that the impact of invasive plants on topsoil chemical properties varied depending on the initial site conditions. For a single species, impacts on topsoil chemical properties were either positive (i.e. increased values of the parameter in invaded plots compared to uninvaded plots), negative (decreased values of the parameter in invaded plots compared to uninvaded plots) or not significant. This is exemplified by $H$. mantegazzianum: $\mathrm{K}$ increased $\left(+135 \mathrm{mg} \mathrm{kg}^{-1}\right)$ at one site invaded by this species, while at another site which it invaded, $\mathrm{K}$ decreased $\left(-86 \mathrm{mg} \mathrm{kg}^{-1}\right.$ ) (Fig. 1). The same was true for $\mathrm{Mg}$ in sites invaded by $F$. japonica $\left(+128 \mathrm{mg} \mathrm{kg}^{-1}\right.$ in one site vs. $-85 \mathrm{mg} \mathrm{kg}^{-1}$ in another), for $\mathrm{P}$ in sites invaded by $S$. gigantea $\left(+13 \mathrm{vs} .^{-48} \mathrm{mg} \mathrm{kg}^{-1}\right)$ and for Mn in sites invaded by I. glandulifera (+10 vs. $\left.-54 \mathrm{mg} \mathrm{kg}^{-1}\right)$ (Fig. 1).

Interestingly, the magnitude of the impacts of plant invasion on topsoil chemical properties, expressed as the difference between values of the parameters in invaded stands $(I)$ and uninvaded stands $(U)$, showed a remarkable pattern (Fig. 1). Thus, positive impacts (i.e. increased values in invaded plots compared to uninvaded plots) were most often observed in sites with low values in the uninvaded plots. In contrast, sites with relatively high concentration values in the soil prior to invasion (uninvaded plots) tended to show negative impacts, i.e. decreased values in invaded plots compared to uninvaded plots. The correlation between impact magnitude and initial conditions was negative for all parameters (Fig. $1)$.

This pattern was confirmed by regression analysis. In this analysis, soil values in invaded plots $(I)$ were regressed against values in uninvaded stands $(U)$. The equation of the regression line was calculated $(I=b+a U)$, and conformity tests of the slope $(a)$ and intercept $(b)$ were performed. There was a highly significant, positive correlation between $I$ and $U$ for all parameters (Table 3 ). The slope of the regression line was systematically $<1$ and intercepts were systematically $>0$. This was significant for all variables except $\mathrm{Zn}, \mathrm{C}$ and $\mathrm{pH}$. Thus, impacts varied with initial conditions. In sites with low nutrient concentrations in the soil, invasion tended to increase nutrient concentrations, while in sites with high nutrient concentrations, the opposite pattern-i.e. decreased concentrations in invaded stands-was most often observed.

\section{Biomass}

There was a 77-fold variation in aboveground biomass in uninvaded plots, which is in line with the large variation in vegetation structure in our sample. Senecio inaequidens sites generally had a very low biomass in terms of the resident vegetation ( $80 \mathrm{gm}^{-2}$ on average). In all sites, the biomass was always higher for the invaded than the uninvaded 
vegetation (on average, F. japonica 2.95 vs. $0.56 \mathrm{~kg} \mathrm{~m}^{-2}$, S. gigantea $0.99 \mathrm{vs.} 0.47 \mathrm{~kg} \mathrm{~m}^{-2}$, I. glandulifera $1.0 \mathrm{vs.} 0.68 \mathrm{~kg}$ $\mathrm{m}^{-2}$, S. inaequidens $0.24 \mathrm{vs} .0 .08 \mathrm{~kg} \mathrm{~m}^{-2}$ ). The biomass increase was highly significant for all species (tests not shown).

Table 3. Conformity tests for slope (a) and intercept (b) of the linear regression line of topsoil chemical properties in invaded (I) versus uninvaded (U) plots $(I=b+a U)$.

\begin{tabular}{llllll}
\hline Chemical properties & $\boldsymbol{r}$ & $\boldsymbol{a} \pm \mathbf{S E}$ & $\boldsymbol{t}$ & $\boldsymbol{b} \pm \mathbf{S E}$ & $\boldsymbol{t}$ \\
\hline $\mathrm{pH}$ & $0.98^{* * *}$ & $0.11 \pm 0.21$ & $0.5 \mathrm{NS}$ & $0.96 \pm 0.036$ & $0.9 \mathrm{NS}$ \\
$\mathrm{K}$ & $0.82^{* * *}$ & $41 \pm 14$ & $2.9^{* *}$ & $0.80 \pm 0.09$ & $2.1^{*}$ \\
$\mathrm{C}$ & $0.89^{* * *}$ & $8600 \pm 5100$ & $1.7 \mathrm{NS}$ & $0.82 \pm 0.07$ & $2.4^{*}$ \\
$\mathrm{~N}$ & $0.69^{* * *}$ & $1200 \pm 400$ & $5.2^{* * *}$ & $0.53 \pm 0.10$ & $4.8^{* * *}$ \\
$\log \mathrm{Mg}$ & $0.93^{* * *}$ & $0.42 \pm 0.12$ & $3.3^{* *}$ & $0.82 \pm 0.06$ & $3.0^{* *}$ \\
$\log \mathrm{P}$ & $0.86^{* * *}$ & $0.32 \pm 0.09$ & $3.6^{* *}$ & $0.74 \pm 0.08$ & $3.3^{* *}$ \\
$\log \mathrm{Mn}$ & $0.90^{* * *}$ & $0.37 \pm 0.08$ & $4.5^{* * *}$ & $0.75 \pm 0.06$ & $4.0^{* * *}$ \\
$\log \mathrm{Zn}$ & $0.96^{* * *}$ & $0.079 \pm 0.048$ & $1.6 \mathrm{NS}$ & $0.94 \pm 0.04$ & $1.3 \mathrm{NS}$
\end{tabular}

Intercept $(b)$ values $>0$ and $<0$ indicate positive and negative impacts, respectively. Slope $(a)$ values $>1$ and $<1$ indicate that impacts increase and decrease with initial conditions, respectively. Correlation coeicients $(r), t$ values and significance levels (NS, not significant; ${ }^{*} p<0.05,{ }^{* *} p<0.01$, $\left.{ }^{* * *} p<0.001\right)$. Degrees of freedom $=34$.

Fig. 2. Nutrient stocks in aboveground biomass (mean values for all species in all sites, whiskers are standard deviation) in invaded (black) and uninvaded plots (white). Significance level for invasion impact in the three-way ANOVA: ${ }^{*} p<0.05, * * p<0.01, * * * p<0.001$.

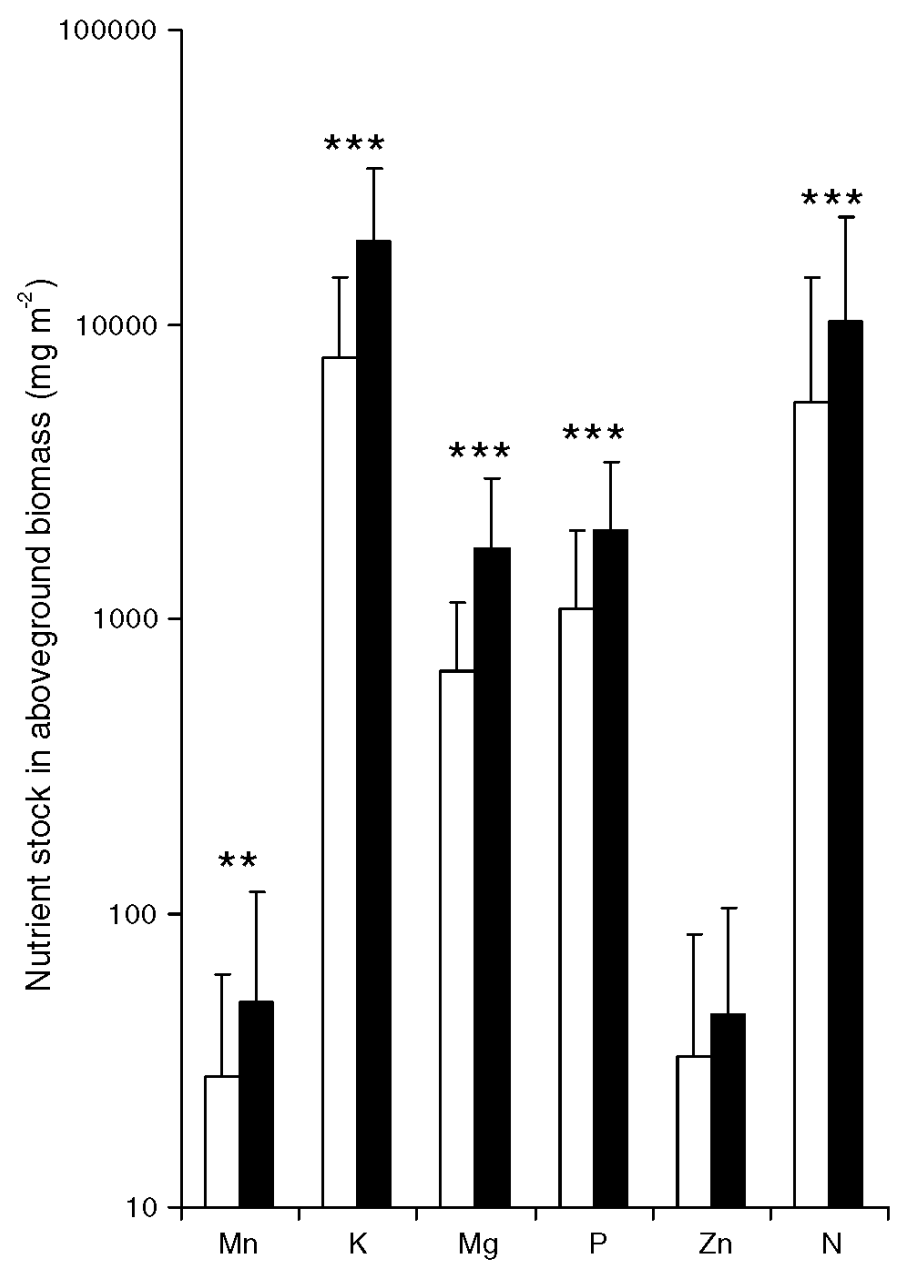




\section{Nutrient concentrations and stocks in plants}

The four species had widely different nutrient concentrations in shoots, with I. glandulifera and $F$. japonica having the highest and the lowest nutrient concentrations, respetively. Compared to the uninvaded vegetation, F. japonica had significantly lower tissue concentrations of all nutrients (K 12,200 vs. $20,700 \mathrm{mg} \mathrm{kg}^{-1}, \mathrm{Mg}_{1150 \mathrm{vs} .1880 \mathrm{mg} \mathrm{kg}}{ }^{-1}, \mathrm{P}$ 1280 vs. $2710 \mathrm{mg} \mathrm{kg}^{-1}$, Mn 31 vs. $35 \mathrm{mg} \mathrm{kg}^{-1}$, Zn 29.1 vs. $45.5 \mathrm{mg} \mathrm{kg}^{-1}$, N 1.10 vs. 1.58\%). Similarly, S. gigantea had a significantly lower tissue concentration of most nutrients (Mg 1380 vs. $1660 \mathrm{mg} \mathrm{kg}^{-1}$, P 1820 vs. 2480 mg kg-1, Mn 41 vs. $54 \mathrm{mg} \mathrm{kg}^{-1}$, N 0.87 vs. $\left.1.16 \mathrm{mg} \mathrm{kg}^{-1}\right)$. Impatiens glandulifera had significantly higher values for $\mathrm{K}(31,100 \mathrm{vs}$. $17,000 \mathrm{mg} \mathrm{kg}^{-1}$ ), $\mathrm{Mg}$ (2320 vs. $1390 \mathrm{mg} \mathrm{kg}^{-1}$ ) and P (2810 vs. $2210 \mathrm{mg} \mathrm{kg}^{-1}$ ), but significantly lower concentrations of $\mathrm{Zn}\left(53.3\right.$ vs. $\left.87.4 \mathrm{mg} \mathrm{kg}^{-1}\right)$ and N (1.32 vs. 1.66\%). Senecio inaequidens had a significantly higher concentration of K $\left(11,500\right.$ vs. $8,230 \mathrm{mg} \mathrm{kg}^{-1}$ ) and $\mathrm{Zn}$ (50.0 vs. $\left.35.8 \mathrm{mg} \mathrm{kg}^{-1}\right)$, but a significantly lower concentration of P (1310 vs. 1770 $\mathrm{mg} \mathrm{kg}^{-1}$ ) than the uninvaded vegetation. Despite contrasting patterns for nutrient concentrations, nutrient stocks were consistently higher in invaded than uninvaded plots for nearly all elements in all species (Fig. 2). This was reflected in the results of the three-way ANOVA where the invasion efect was significant for all elements except Zn (Fig. 2).

\section{DISCUSSION}

\section{Impacts on soil nutrient pools are strongly correlated to initial soil conditions}

Recent reviews have concluded that, on average, alien invasive plants increase nutrient pools and luxes in invaded ecosystems. However, high variability in the response to invasion has been observed (Ehrenfeld 2003; Liao et al. 2008). Our results highlight the importance of site as a most important source of variation in the impacts of alien invasive species on soil nutrient pools. The picture emerging from our study is not one of idiosyncratic impacts. The direction and magnitude of the alterations of soil chemical properties show a striking pattern, being strongly correlated to soil chemical properties prior to invasion. Specifically, large positive impacts are most often found in sites with small pools of nutrients in the topsoil. Impact magnitude decreases with increasing site nutrient status and eventually becomes negative in sites with the largest initial nutrient pools in the topsoil. This pattern holds true for all elements and is significant for $\mathrm{K}, \mathrm{Mg}, \mathrm{P}, \mathrm{Mn}$ and $\mathrm{N}$. Up to $45 \%$ of the variance in impacts is accounted for by initial site conditions. This is a remarkable result considering that our sample comprises 35 sites spanning a broad range of habitat conditions and seven species with widely divergent growth forms. Such a pattern has not been reported before, possibly because earlier studies have considered a limited number of sites and/or because eutrophic sites were underrepresented.

Elucidating the mechanisms by which alien plant invasion may alter topsoil nutrient pools requires detailed assessment of nutrient budgets in invaded and uninvaded systems. This was beyond the scope of this paper. However, our data provide some cues into the mechanisms of the observed pattern, which are discussed in the following sections.

\section{Alien invasive species increase biomass and nutrient stocks in standing biomass}

In our study, the invaded plots consistently had higher aboveground biomass and nutrient standing stocks in shoots compared to uninvaded vegetation, which is in agreement with many earlier reports (Ehrenfeld et al. 2001; Blank and Young 2002; Ehrenfeld 2003; Wilsey and Polley 2006; Liao et al. 2008). Higher biomass is achieved either by larger shoots and faster growth rate (F. japonica, I. glandulifera, S. gigantea) or by increased ground cover compared to the resident vegetation (S. inaequidens).

In all cases, we found that higher aboveground biomass was a key attribute explaining the higher nutrient standing stocks. In contrast, tissue nutrient concentrations were much more variable among the alien invasive species. For some elements, especially $\mathrm{N}$, we found that the invasive species actually had lower concentrations than the resident vegetation. This is apparently at odds with earlier studies showing higher concentrations of nutrients in invasive species (Baruch and Goldstein 1999; Ehrenfeld et al. 2001; Blank and Young 2002). This apparent discrepancy may be explained by the fact that our data refer to whole shoots (thus including nutrient-poor stems), while only foliar concentrations were analysed in most published studies.

Higher nutrient stocks in shoots must result in increased nutrient returns in litterfall. This was certainly true in the annual I. glandulifera in our study and is most likely true for the perennial species also, except if the invasive species had a considerably higher nutrient resorption from senescing shoots, which seems unlikely. It appears that invasive species steadily enhance specific nutrient luxes in invaded ecosystems, including net uptake rates from soil and annual returns in dead organic matter. 


\section{Increased nutrient pools in topsoil in nutrient-poor sites}

In sites with low to moderate pools of nutrients in the top-soil prior to invasion, our results follow the general trend reported in many published studies, i.e. increased nutrient pools in topsoil in response to invasion (e.g. Musil 1993; Scott et al. 2001; Duda et al. 2003; Vanderhoeven et al. 2005; Chapuis-Lardy et al. 2006). This may be a straightforward consequence of increased luxes of $\mathrm{C}$ and $\mathrm{N}$ in litter returns (Ehrenfeld 2003; Liao et al. 2008). Soils with low organic matter content and sparse vegetation cover which are invaded by plants with a high biomass may accumulate $C$ through higher litter returns. This is true of coastal sand dunes invaded by $R$. rugosa. Such an effect may not be specific of alien invasive species, as it is also observed during natural succession from open herbaceous vegetation to closed shrub vegetation in dunes (Kovel et al. 2000). In their recent review, Liao et al. (2008) attribute the higher $\mathrm{C}$ stock in invaded soils to the generally higher net primary productivity of invasive species. The increased $\mathrm{N}$ stock in the topsoil can directly result from the higher $\mathrm{C}$ inputs into soil, which provide more carbohydrates for $\mathrm{N}$ fixation by soil microbes (Knops et al. 2002). It can also result from enhanced asymbiotic atmospheric $\mathrm{N}$ fixation in invaded plots (Ley and D'Antonio 1998).

Increased concentrations of exchangeable cations and $\mathrm{P}$ in the topsoil may have other explanations. First, nutrient uplift from deep soil layers is a well-known mechanism by which deep-rooted species can move nutrients up to the topsoil (Blank and Young 2002; Dijkstra and Smits 2002; Jobbagy and Jackson 2004). Several invasive species in our sample do root at a deeper depth compared to the native vegetation ( $F$. japonica, H. mantegazzianum and possibly also $P$. serotina and $R$. rugosa) and may thus tap nutrients from a pool larger than that available to the resident vegetation. The extra nutrients supplied to topsoil in the litter of alien invasive species may be more efficiently retained in the topsoil (e.g. in microbial biomass) of nutrient-limited sites than in eutrophic sites. Increased soil organic matter content may also enhance cation exchange capacity, thus promoting nutrient retention in topsoil.

Secondly, alien species can also increase the availability of nutrients without changing total pools. For example, increased inorganic P concentrations in the topsoil under S. gigantea has been explained by decreased soil $\mathrm{pH}$ and an enhanced production of phosphomonoesterase (Chapuis-Lardy et al. 2006). Such an active mobilisation of nutrients by rhizospheric processes is more likely to occur in nutrient-limited sites (McGill and Cole 1981; Fox and Comer-ford 1992; Gilbert et al. 1999; Wasaki et al. 2003) and may thus explain decreasing impacts with increasing nutrient fertility.

\section{Decreased pools of nutrients in the topsoil in nutrient-rich soil}

The decreased pools of nutrients in the topsoil in nutrient-rich soil is a more surprising result. It suggests that, in response to invasion, the balance of gains and losses of nutrients becomes increasingly negative as site fertility increases. Nutrients may be less strongly immobilised in the topsoil in the most fertile sites than in the nutrient-limited sites (Tamm et al. 1995). This may result in "nutrient leakage". Organic matter turnover rates and nutrient leaching losses are often increased in eutrophic sites (Wedin and Tilman 1996; Debusk and Reddy 1998). In NW Europe, eutrophic sites are most often invaded by F. japonica, S. gigantea, I. glandulifera and H. mantegazzianum. All of these species do not cover the soil surface during winter and spring; this is in contrast to the resident vegetation, which is mostly composed of perennial grass species that maintain a minimal $\mathrm{N}$ uptake, thereby preventing mineral $\mathrm{N}$ leaching (Hooper and Vitousek 1998; Ridley et al. 2001). In highly eutrophicated sites, plants that leave the soil uncovered for months in winter and spring may stimulate organic matter mineralisation and nutrient leaching. Bare soil is also more prone to erosion.

\section{Convergence and homogenisation of soil chemical properties}

Opposite impacts of alien invasive species in nutrient-poor versus nutrient-rich sites should result in the convergence of invaded plots towards similar values of topsoil chemical properties. Our data offer some support to this hypothesis. The element concentrations in the topsoil at our sites varied within narrower limits in invaded (I) plots compared to uninvaded $(U)$ ones, most strikingly so for Mn (44-fold variation among $U$ plots vs. 15 -fold in $I$ plots), K (45-fold v22fold), P (40-fold vs. 22-fold), Mg (35-fold vs. 23-fold), N (32-fold vs. 21-fold) and Zn (248-fold vs. 174-fold). The convergence of soil chemical properties in invaded plots may not be surprising, considering that invasion results in the convergence of plant community composition. In our study, plant community composition before invasion was extremely variable among sites. The replacement of all of these communities by monospecific stands of a small group of alien invasive species which share functional traits (high net primary productivity) may conceivably result in some form of convergence in soil chemical properties. 
It has been suggested that alien invasive species may result in biotic homogenisation (Vitousek et al. 1996; Olden and Poff 2003; McKinney 2004). Our results provide the first indication that highly successful alien invasive species may promote the homogenisation of soil conditions in invaded landscapes.

\section{CONCLUSION}

In NW Europe, even though alien invasive species generally increase aboveground nutrient standing stocks, their impacts on topsoil chemical properties show large variations that are site-dependent. Much of this variation is explained by topsoil chemical properties prior to the invasion. The convergence of topsoil chemical properties due to the invasion by those species may contribute to ecosystem homogenisation. This conclusion should be tested in other edaphic contexts, using invaded stands of known age. Elucidating the mechanisms of that pattern will require detailed comparative assessments of nutrient budgets in invaded and uninvaded systems along soil fertility gradients. This work is currently in progress in sites invaded by F. japonica.

\section{Acknowledgments}

This work has been supported by the Belgian Science Policy and is part of the project "INPLANBEL: Invasive Plants in Belgium: Patterns, Processes and Monitoring" (Science for Sustainable Development, contract EV/11/27C). We would like to thank E. Rossi and I. Nijs (University of Antwerp) for the $\mathrm{C}$ and $\mathrm{N}$ analyses and A. Demoulin for logistic assistance. The experiments of this study comply with the current laws of Belgium.

\section{References}

Alpert P, Bone E, Holapfel C (2000) Invasiveness, invasibility and the role of environmental stress in the spread of non-native plants. Perspect Plant Ecol Evol Syst 3:52-66

Alvarez ME, Cushman JH (2002) Community-level consequences of a plant invasion: effects on three habitats in coastal California. Ecol. Appl. $12: 1434-1444$

Asner GP, Beatty SW (1996) Effects of an African grass invasion on Hawaiian shrubland nitrogen biogeochemistry. Plant Soil 186:205-211

Baruch Z, Goldstein G (1999) Leaf construction cost, nutrient concentration, and net CO2 assimilation of native and invasive species in Hawaii. Oecologia 121:183-192

Belnap J, Philips SL (2001) Soil biota in an ungrazed grassland: response to annual grass (Bromus tectorum) invasion. Ecol. Appl. 11:1261-1275

Blank RR, Young JA (2002) Inluence of the invasive crucifer, Lepidium latifolium, on soil properties and elemental cycling. Soil Sci 167:821-829

Braithwaite RW, Lonsdale WM, Estbergs JA (1989) Alien vegetation and native biota in tropical Australia: the impact of Mimosa pigra. Biol. Conserv. 48:189-210

Chapuis-Lardy L, Vanderhoeven S, Dassonville N, Koutika LS, Meerts P (2006) Effect of the exotic invasive plant Solidago gigantea on soil phosphorus status. Biol Fertil Soils 42:481-489

Christian JM, Wilson SD (1999) Long-term ecosystem impacts of an introduced grass in the northern Great Plains. Ecology 80:23972407

D'Antonio CM (1992) Biological invasions by exotic grasses, the grass/fire cycle, and global change. Annu Rev Ecol Syst 23:63-87

Davis MA, Grime JP, Thompson K (2000) Fluctuating resources in plant communities: a general theory of invasibility. J Ecol. 88:528-534

Debusk WF, Reddy KR (1998) Turnover of detrital organic carbon in a nutrient-impacted Everglades marsh. Soil Sci Soc Am J 62:1460-1468

Dijkstra FA, Smits MM (2002) Tree species effects on calcium cycling: the role of calcium uptake in deep soils. Ecosystems 5:285-398

Duda JJ, Freeman DC, Emlen JM, Belnap J, Kitchen SG, Zak JC, Sobek E, Tracy M, Montante J (2003) Differences in native soil ecology associated with invasion of the exotic annual chenopod, Halogeton glomeratus. Biol Fertil Soils 38:72-77

Ehrenfeld JG (2003) Effects of exotic plant invasions on soil nutrient cycling processes. Ecosystems 6:503-523

Ehrenfeld JG, Kourtev P, Huang W (2001) Changes in soil functions following invasions of exotic understory plants in deciduous forests. Ecol Appl $11: 1287-1300$

FAO, ISRIC, IUSS (1998) World reference base for soil resources. FAO report 84. Food and Agriculture Organization (FAO), Rome 
Published in: Oecologia (2008), vol. 157, issue 1, pp. 131-140

Statut: Postprint (Author's version)

Fox TR, Comerford NB (1992) Rhizosphere phosphatase activity and phosphatase hydrolysable organic phosphorus in two forested Spodosols. Soil Biol Biochem 24:579-583

Gilbert GA, Knight JD, Vance CP, Allan DL (1999) Acid phosphatase activity in phosphorus-deicient white lupin roots. Plant Cell Environ 22:801810

Grotkopp E, Rejmanek M, Thomas Rost L (2002) Toward a causal explanation of plant invasiveness: seedling growth and life history strategies of 29 Pine (Pinus) species. Am Nat 159:396-419

Hooper DU, Vitousek PM (1998) Effects of plant composition and diversity on nutrient cycling. Ecol Monogr 68:121-149

Jobbagy EG, Jackson RB (2004) The uplift of soil nutrients by plants: biogeochemical consequences across scales. Ecology 85:23802389

Knops JMH, Bradley KL, Wedin DA (2002) Mechanisms of plant species impacts on ecosystem nitrogen cycling. Ecol Lett 5:454-466

Kovel CGF, Mierlo AJEM, Wilms YJO, Berendse F (2000) Carbon and nitrogen in soil and vegetation at sites differing in successional age. Plant Ecol. 149:43-50

Leary JK, Hue NV, Singleton PW, Borthakur D (2006) The major features of an infestation by the invasive weed legume gorse (Ulex europaeus) on volcanic soils in Hawaii. Biol Fertil Soils 42:215-223

Ley RE, D'Antonio CM (1998) Exotic grass invasion alters potential rates of N fixation in Hawaiian woodlands. Oecologia 113:179-187

Liao C, Peng R, Luo Y, Zhou X, Wu X, Fang C, Chen J, Li B (2008) Altered ecosystem carbon and nitrogen cycles by plant invasion: a meta-analysis. New Phytol 177:706-714

McGill WB, Cole CV (1981) Comparative aspects of cycling of organic C, S, N and P through soil organic matter. Geoderma 26:267-286

McKinney ML (2004) Measuring loristic homogenization by non-native plants in North America. Glob Ecol Biogeogr 13:47-53

Meyerson LA, Saltonstall K, Windham L, Kiviat E, Findlay S (2000) A comparison of Phragmites australis in freshwater and brackish marsh environments in North America. Wetland Ecol. Manage 9:89-103

Muller S (2004) Invasives en France. Museum d'Histoire Naturelle, Paris Musil CF (1993) Effect of invasive Australian acacias on the regeneration, growth and nutrient chemistry of South African lowland fynbos. J Appl Ecol 30:361-372

Olden JD, Pof NL (2003) Toward a mechanistic understanding and prediction of biotic homogenization. Am Nat 162:442-460

Pysek P (1991) Heracleum mantegazzianum in the Czech republic - dynamics of spreading from the historical perspective. Folia Geo-bot Phytotox 26:439-454

Pysek P, Prach K (1995) Invasion dynamics of Impatiens glandulifera - a century of spreading reconstructed. Biol Conserv 74:4148

Ridley AM, White RE, Helyar KR, Morrison GR, Heng LK, Fisher R (2001) Nitrate leaching loss under annual and perennial pastures with and without lime on a duplex (texture contrast) soil in humid southeastern Australia. Eur J Soil Sci 52:237-252

Scott NA, Saggar S, McIntosh PD (2001) Biogeochemical impact of Hieracium invasion in New Zealand's grazed tussock grasslands: sustainability implications. Ecol Appl 11:1311-1322

StatSoft Inc (2005) STATISTICA (Data analysis software) version 7. Available at: http:www.statsoft.com.

Stock WD, Wienand KT, Baker AC (1995) Impacts of invading N2-fixing Acacia species on patterns of nutrient cycling in two Cape ecosystems: evidence from soil incubation studies and ${ }^{15} \mathrm{~N}$ natural abundance values. Oecologia 101:375-382

Tamm CO, Aronsson A, Popovic B (1995) Nitrogen saturation in a long-term forest experiment with annual additions of nitrogen. Water Air Soil Pollut 85:1683-1688

Vanderhoeven S, Dassonville N, Meerts P (2005) Increased topsoil mineral nutrient concentrations under exotic invasive plants in Belgium. Plant Soil 275:167-177

Verloove F (2002) Ingeburgerde plantensoorten in Vlaanderen. Instituut voor Natuurbehoud, Brussels

Verloove F (2006) Catalogues of neophytes in Belgium (1800-2005), vol 39. Scripta Botanica Belgica, Meise

Vitousek PM, D'Antonio CM, Loope LL, Westbrooks R (1996) Biological invasions as global environmental change. Am Sci. 84:468-478 
Published in: Oecologia (2008), vol. 157, issue 1, pp. 131-140

Statut: Postprint (Author's version)

Wasaki J, Yamamura T, Shinano T, Osaki M (2003) Secreted acid phosphatase is expressed in cluster roots of lupin in response to phosphorus deficiency. Plant Soil 248:129-136

Wedin DA, Tilman D (1996) Influence of nitrogen loading and species composition on the carbon balance of grasslands. Science 274:1720-1723

Williamson M, Pysek P, Jarosik V, Prach K (2005) On the rates and patterns of spread of alien plants in the Czech Republic, Britain, and Ireland. Ecoscience 12:424-433

Wilsey BJ, Polley HW (2006) Aboveground productivity and root-shoot allocation differ between native and introduced grass species. Oecologia 150:300-309 